\section{PASCAL TERCENTENARY CELEBRATION}

$\mathrm{I}^{\mathrm{N}}$ 1642 Blaise Pascal, a Frenchman, invented the first calculating machine. The tercentenary of this event, which has had such a profound influence upon applied mathematics and physics, should appropriately have been celebrated this year in Paris. In order that the date should not pass unnoticed, a small committee was formed, under the chairmanship of Dr. L. J. Comrie, to arrange a commemorative luncheon followed by an exhibition of calculating machines. Other members of the committee were an eminent Frenchman of science now in Great Britain, Mr. W. Desborough and Mr. R. S. Nilsson, a Swedish engineer. The celebration was held on October 19 at the Connaught Rooms, London. The 120 guests who attended the luncheon included those who design calculating machines, those who make them, those who use them, and several members of the Fighting French, including an official deputation from General de Gaulle's headquarters.

After the toasts "The King" and "La France Combattante", the chairman recalled that it was in the year of Galileo's death and of Newton's birth that Pascal invented the first calculating machine. A replica of this machine, made by Mr. Nilsson, stood on a table before him. Mr. Nilsson had also made a replica of the first English calculating machine, made by Samuel Morland in 1666, which was on show in the exhibition room. Many of those present, Dr. Comrie continued, would know of the great tercentenary held in Edinburgh in 1914 to commemorate the discovery of logarithms by Napier. Had it not been for the War, the French would certainly have held a celebration on a similar scale in honour of Pascal. It was found that two people present, Prof. T. Arnold Brown and Mr. F. E. Guy, had also attended the Napier tercentenary celebrations.

Dr. Comrie next welcomed the many distinguished French men of science and representatives of the Fighting French. $\mathrm{He}$ mentioned particularly $\mathrm{Mme}$. Weill, a former associate of Mme. Curie, and Prof. Cathala, who had travelled from Scotland for the occasion. The Norwegian Government and the Swedish Legation were also officially representeda reminder of the Swedish engineers Scheutz, Odhner, Sundstrand, Fridèn, Rudin and others, who had contributed to the evolution of calculating machines.

Dr. Comrie then called on Prof. S. Chapman, president of the Royal Astronomical Society, to propose the toast "Blaise Pascal-the inventor of the first calculating machine", saying that Prof. Chapman had a special claim to propose this toast, since in his capacity as professor of mathematics at the Imperial College he had been one of the pioneers in introducing the study of calculating machines and numerical methods into academic courses, and had also introduced them with conspicuous success into his own geophysical and other researches. Prof. Chapman's address is printed on p. 508 in this issue.

The reply was by Prof. René Cassin, Commissaire National à la Justice et l'Instruction Publique de la France Combattante. He thanked the committee, on behalf of the French in Great Britain, for their enterprise in arranging this celebration in honour of Pascal. $\mathrm{He}$ stressed the versatility of Pascal's genius: at the age of nineteen, when he invented the calculating machine-essentially a practical instrument-Pascal was already well known in the realm of pure mathe. matics. His perseverance with this invention helped one to appreciate more fully the character of Pascal. $\mathrm{He}$ had to fight not only ill-health but also the ignorance of his time, for his conception far outstripped the mechanical experience and ability of those to whom the work was entrusted. It was not until Pascal had made more than fifty models that he achieved his final design.

The invention of the calculating machine illustrated Pascal's extraordinary creative imagination, allied with mathematical genius and precision, and tempered with critical penetration. These qualities were characteristic of the man throughout his life. Prof. Cassin spoke of Pascal's conviction, also can. didly expressed in his letter to Queen Christine of Sweden, that learning was greater than the power of princes-"Toute notre dignité consiste en la pensée. Travaillons done à bien penser : voilà le principe de la Morale". It was stimulating to remember this defence of liberty of thought at a time when political tyrants tried to turn men into machines incapable of thinking, forcing upon those in their power their fanatical ideas. The spirit of Pascal was an inspira. tion of those who strove to restore to France her freedom.

Prof. D. R. Hartree, whose task was to propose a vote of thanks to the speakers, asked to be allowed to include Dr. Comrie in his remarks, saying that the success of the gathering was in great part due to his chairmanship. $\mathrm{He}$ was glad of the opportunity of paying his own tribute to Pascal, not only as the inventor of the calculating machine but also as the worthy representative of the spirit and genius of the French people.

After the luncheon a small exhibition, which was open to the public, was held in an adjoining room. Various types of hand and electric calculating machines and models were shown, and demonstrators explained their working and applications to visitors. Two short lectures were given, one by Dr. Comrie un "Mathematical Gymnastics with Calculating Machines", and the other by Mr. Nilsson on "A Description of Calculating Machine Mechanisms".

M. E. P.

\section{EVOLUTION IN SOCIETY}

GIR WALTER LANGDON-BROWN, in his $\checkmark$ presidential address to the British Social Hygiene Council on October 12, discussed "The Place of Social Biology in the Sciences". He indicated that the interdependence of all life is shown by the fact that at every stage of the journey, from the apparently inert mineral to the conscious intelligent being, the 'laws' governing the lower levels apply to the higher, though the latter also develop new laws of their own. The most complex plant has to obey the ordinary laws of chemical combination as faithfully as has the soil from which it springs, but in addition it has acquired the capacity for building up food reserves by photosynthesis. Animals have acquired kinetic energy for which they are dependent on the potential energy of the plant, and they can effect, through catalysts, chemical reactions at ordinary temperatures which can only be imitated in the laboratory under conditions incompatible with life. The same holds for the progressive stages from simple reflex action through instinct to intelligence. At each 
step something fresh is added to the old law. Presumably this applies also to the still higher values of life. Yet though man lives by this balance of Nature, he is too apt to act like a bandit of the soil, converting fertile lands into deserts. The urgency of this matter is at once obscured but really intensified by urbanization.

Man is a gregarious animal and cannot live in isolation without dire injury to himself. Here biology and sociology are at one. Maudsley said "there could not be a greater danger to the balance of any mind than to be exempt from the bonds and pressure of the surrounding social system". Dictators illustrate that truth. Sir Arthur Keith has directed attention to two opposing tendencies in life - one the general demand of evolution for enlargement of the unit, the other the species-making impulse to segregate a particular type. The former makes for internationalism, the latter for nationalism. The present fanatical outbreak is the frightened and pathological response of the species-making impulse faced by the imperious demands of evolution. The nervous system was developed to allow of rapid co-operation between the various organs of the individual, and rapid communication is essential to the co-ordination of the complex civilization of to-day. The present issue is clear-cut : Do individuals exist for the State or the State for individuals ? It is quite possible to win the war and yet to lose on that issue.

The human unit which must be conserved is the family. The child must be confident of security in one person and that person the mother. Mother love was the first moral value to emerge. Father love came later with the longer dependence of the young in the higher forms of life. Children of the same parents differ not only innately in their genes, but, as Adler pointed out, in their environment according to their position in the family, as can be seen by comparing the different reactions of the eldest, the second and the youngest. It is inevitable that for good or ill what the child makes of life will largely depend on the family life he has experienced. The serious misfits are usually the products of unhappy homes. To quote Prof. Wood-Jones, "if we realize that we . . . like all creatures have a part to play in a cosmic process greater than any individual, then we are likely to take a humbler and more balanced view of ourselves".

\section{FORTHCOMING EVENTS}

(Meetings marked with an asterisk are open to the public)

Saturday, October 31

INSTITUTE OF PHYSICS (ELECTRONICs GROUP AND MIDTAND BRANCH) (at the College of Technology, Rugby), at 2.45 p.m.-Dr. D. Gabor : "Wlectron Optics".

Assoolation ox ScrantTFio WorkeRs (at the Royal Photographic Society, 16 Prinees Gate, South Kensington, London, S.W.7), at 8 p.m.-Exhibition of "Photography in Science

\section{Tuesday, November 3}

KODAK, LTD. (at Kodak House, Kingsway, London, W.C.2), at 2 p.m. - Exhibition of "Photography's Part in the War" (to be opened by the Rt. Hon. Lord Brabazon of Tara).

SOCLETY OF CHFMIOAL INDUSTRY (JOINT MEMING OF THE FOOD GROUP WITH THE AGRIOULTURE GROUP) (at the London School of Hygiene and Tropical Medicine, Keppel Street, London, W.C.1), at 2.30 p.m. -Dr. G. H. Bates: "Increasing the Food Output of Great Britain".

ROYAT, INSTITUTron (at 21 Albemarle Street, London, W.1), at 3 p.m.-Sir James Jeans, O.M., F.R.S.: "Evolution in Astronomy", 1." Wednesday, November 4

Assoctamion or SctenTFFic Workans (at the Royal Photographic Society, 16 Princes Gate, South Kensington, London, 8.W.7), at 6.30 p.m.-Dr. D. A. Spencer: "Photography as a Tool".
Thursday, November 5

Town and Cotntry Planning Assooratron (in the Lounge of the Y.M.C.A., Central Buildings, Great Russell Street, London, W.C.1) at 1.15 p.m.-Mr. G. A. Jellicoe : "Landscape Architecture and Planning".

INSTITUTION OF ELECTRICAL FINGINEIES (JOINT MEETING WITH THE INSTTTUTION OF MEOHANICAT, ENGINARRS) (at Savoy Place, viotoria Embankment, London, W.C.2), at 5.30 p.m.-Mr. J. N. Waite : "Coal for Steam Raising".

\section{Friday, November 6}

Physiod4 Socikrx (in the Lecture Theatre of the Science Museum, Fxhibition Road, South Kensington, London, S.W.7), at 4.30 p.m.Prof. H. R. Robinson, F.R.S.: "Rutherford, Life and Work to the Year 1919, with Personal Reminiscence

RoYAI INSTITUTion (at 21 Albemarle Street, London, W.1), at Roral INSTTTUTION (at 21 Albemarle Street, London, W.1), at
5 p.m.-Prof. W. V. Mayneord : "The Measurement of Radiation for 5 p.m.- Prof. W. V.

INSTITUTION of Modraniond ENGINiers (at Storey's Gate, St. James's Park, London, S.W.1), at 5.30 p.m.-Lord Dudley G. Gordon : "Recent Developments in Refrigeration" (Thomas Hawksley Lecture)

Association of SCIENTIFIO Workers (at the Royal Photographic Society, 16 Princes Gate, Sonth Kensington, London, 8.W.7) a 6.30 p.m. $\rightarrow$ Mr. E. D. Eyles: "Some Applications of High-Speed Photography".

Saturday, November 7

Brochemical Sociwery (in the Department of Organic Chemistry Imperial College of Science and Technology, South Kensington, Lon don, S.W.7), at 11 a.m. : Discussion on "The Theory and Application of Chromatographic Methods to Biological Problems".

\section{Saturday-Sunday, November 7-8}

ASSOCIATIOY OF SPECIAL IIBRARIES AND INFORMATTOY BTREATX (at the Royal Society, Burlington House, Piccadilly, W.1).

Saturday

At 11 a.m.: Annual General Meeting. At 12 noon: Sir Richard Gregory, Bart., F.R.S.: "International Systems and Standards"

Sunday

At 10.30 a.m. : Symposium on Microfllm.

\section{APPOINTMENTS VACANT}

APPLIOATIONS are invited for the following appointments on or before the dates mentioned :

LRCTURER IN MECHANICAI ENGINEERING with some knowledge of The Principal, College of Technology and Commerce, Ieicester (November 7).

Teaufir of Meohanical Engineming-The Principal, Wolverton Technical College, Wolverton, Bucks. (November 7).

InstruCtor in ENGINERRING WORKSHOP PRACTIOE at the Llanelly Mining and Technical Institute-The Director of Education, Education Department, County Hall, The Castle, Carmarthen (November 7). LEOTURER IN MROHANICAL ENGINGIRING at the Constantine Techical College-The Direct

HRAD OF THE Mining Department of the Chesterfield Technical College-The Clerk to the Governors, Technical College, Infirmary Road, Chesterfleld (November 9).

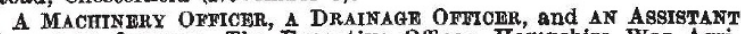
DrasNagR OFFIOER - The Executive Officer, Hampshire War Agri(the Iondon DEMonsto (Royal Free Hosplte Reed Hall, Streatham Drive, Exeter (November 19).

I FCTURBR IN Mathematics-The Principal, Stockport College for Further Education, Stockport.

\section{REPORTS and other PUBLICATIONS (not included in the monthly Books Supplement) Great Britain and Ireland}

The Scientific Journal of the Royal College of Science. Vol. 12 : ontaining Papers read during the Sesgion 1941-1942 before the (hoyel College of Science The Royal Mathemal History Society. Pp. vi +158. (London: Royal College of Science.) Paper, 48.; cloth, 58. 6 d.
[710 Medical Research Council. Special Report Series, No. 246 : Report of the Committee on Tuberculosis in War-Time. Pp. 36. (London: H.M. Stationery Office.) $9 d$. net.

$[710$

\section{Other Countries}

U.8. Department of Agriculture. Technical Bulletin No. 813 : Golu. Materials of Soils in relation to their Classiflcation and General Colutily. Br M. Anderson, Mary G. Keyes and teorge W. Cromer. Pp. 79. (Washington, D.O.: Government Printing Office.) 15 cents. 